\title{
Clinton to head 'one-stop shop' for science and technology policy
}

Washington. President Bill Clinton is to chair a new National Science and Technology Council which is being set up to oversee US science and technology policy. The goal of the administration is to exert stronger central control over the $\$ 76$ billion that the federal government spends each year on research and development.

Plans for the new body, which go further than any previous initiative to coordinate the research activities of separate and often competing government agencies, are included in the report of Vice President $\mathrm{Al}$ Gore's National Performance Review, published in Washington last week.

Like other elements in Gore's package - explicitly intended to "reinvent government" - the plans for the proposed council have still to face scrutiny in Congress. Many are likely to see them not only as a threat to the independence of existing agencies, but to the power of the congressional committees that oversee these bodies.

The vice president will be a member of the council, as will the heads of the main science-funding agencies, such as the National Aeronautics and Space Administration (NASA) and the National Science Foundation. The council will also include senior representatives - probably deputy secretaries - of relevant government departments, including energy, commerce, health and human services, defence and agriculture.

Details of the plan will be announced next week by the Office of Science and Technology Policy (OSTP). A draft version will also be circulated of an executive order establishing the new council, which will replace the existing Federal Coordinating Council for Science, Engineering and Technology (FCCSET).

The consultation process for such administrative changes would normally require around six weeks. But OSTP officials say they hope to complete it more rapidly, and to issue the final version of the order early in October.

The contents of the order will indicate just how much power the new council aspires to hold. Important issues still to be resolved include the exact composition of the council, and whether it will be able to issue directives that will be binding on government agencies.

The tough language of the Gore report implies that the council will indeed be given such powers. It complains that the existing FCCSET “can't compel agencies to participate in projects, nor can it tell agencies how to spend funds". And it adds: "At a time of declining federal resources, experts in busi- ness, academia, and government recognize the need for one-stop shopping for science and technology policy."

OSTP sees the council as developing into the principal national body for science and technology policy, comparable to such

\section{IMAGE UNAVAILABLE FOR COPYRIGHT REASONS}

John Gibbons: presidential science adviser and architect of the new council.

powerful existing bodies as the National Security Council and the National Economic Council.

The need for such a powerful coordinating body has been frequently expressed in the past, and the council has been warmly welcomed by the scientific community. Frank Press, President Jimmy Carter's science adviser and a former president of the National Academy of Sciences, says: "The fact that the President will chair the Council will send a clear message through the government that science is a priority area."

The National Performance Review also promised legislation to give the council the teeth it needs, in the review's words, to "direct science and technology policy more forcefully". Some of the required legislation has already been drafted and privately considered by the relevant congressional committees. The new council will also absorb the work of two existing but moribund bodies, the National Space Council and the National Critical Materials Council.

The proposals are the brainchild of John Gibbons, the presidential science adviser and OSTP director, who has already made public his desire to strengthen the FCCSET coordinating panels set up by his predecessor, D. Allan Bromley (see Nature 363, 291; 1993).

At present, six FCCSET panels serve as forums for coordination between different government agencies in key technology areas. But, says the National Performance Review, they cover only 16 per cent of the total amount that the US government spends on research and development, and they have no power to tell agencies what to do. And
Gore's report says that the panels as at present constituted "lack the teeth to set priorities, direct policy, and participate fully in the budget process".

The administration's proposal to develop such powers is bound to meet resistance both within agencies and in Congress, however. Supporters of NASA, the Department of Energy and the armed forces, for example, can all be expected to resist fiercely any infringement on their independence.

But officials suggest that this resistance could be muted by constituting the council as a 'policy board' which would not direct spending as such. Instead, it would make its influence felt through the administration's powerful Office of Management and Budget, a representative of which would sit on the council, and through the existing interagency coordinating process.

The idea of a coordinating science policy body chaired by a president or prime minister is not new, having been attempted in the United Kingdom and Japan, for example. But such panels have had a mixed track record in effectively controlling the activities of strong and independently minded government departments. Colin Macilwain

\section{UK launches research foresight initiative}

London. One of the cornerstones of the British government's new strategy for science and technology was put in place last week with the first meeting of its Technology Foresight Steering Group, a committee whose creation was promised in last May's white paper (policy document) on research.

The group, chaired by Bill Stewart, the government's chief scientific adviser, is made up of two academics, two government scientists, two research council heads and three industrial research directors.

Based on the experience of Japan and other countries, the group will be responsible for putting together a programme which will, according to the Cabinet Office, "build a consensus on those generic technologies where new developments are likely to yield the greatest economic and social benefits to the UK in the long term".

William Waldegrave, the cabinet minister responsible for science, last week described technology foresight as "encapsulating the theme of partnership which is central to the white paper". A series of regional seminars is being held throughout the country to publicize the programme, and the group is due to report early in 1995 . $\square$ 